\title{
PSYCHOLOGICAL ASPECTS OF DIVING IN SELECTED THEORETICAL AND RESEARCH PERSPECTIVES
}

\section{PSYCHOLOGICZNE ASPEKTY NURKOWANIA W WYBRANYCH PERSPEKTYWACH TEORETYCZNO-BADAWCZYCH}

\author{
ПСИХОЛОГИЧЕСКИЕ АСПЕКТЫ НЫРЯНИЯ В ОТДЕЛЬНЫХ ТЕОРЕТИКО- \\ ИССЛЕДОВАТЕЛЬСКИХ ПЕРСПЕКТИВАХ
}

\section{PSYCHOLOGISCHE ASPEKTE DES TAUCHENS UNTER AUSGEWÄHLTEN THEORETISCHEN UND FORSCHUNGSORIENTIERTEN GESICHTSPUNKTEN}

\section{ASPECTOS PSICOLÓGICOS DEL SUBMARINISMO EN DETERMINADAS PERSPECTIVAS TEÓRICAS Y DE INVESTIGACIÓN}

\author{
Dorota Niewiedział ${ }^{1)}$, Magdalena Kolańska ${ }^{1)}$, Zbigniew Dąbrowiecki ${ }^{2)}$, Mateusz Jerzemowski ${ }^{2)}$, \\ Piotr Siermontowski ${ }^{2)}$, Zdzisław Kobos ${ }^{2)}$, Romuald Olszański ${ }^{2)}$ \\ 1) Department of Human Development Psychology, University of Zielona Góra, Poland \\ 1) Zakład Psychologii Rozwoju Człowieka, Uniwersytet Zielonogórski \\ 2) Department of Maritime and Hyperbaric Medicine, Military Medical Institute \\ 2) Zakład Medycyny Morskiej i Hiperbarycznej, Wojskowy Instytut Medyczny
}

\section{StRESZCZEnIA / ABstracts}

The aim of the article is to conduct a literature review in relation to the psychological aspects of diving. The acquired knowledge can currently be qualified as belonging to various branches of applied psychology, as well as underwater medicine, sports medicine, psychiatry and psychotherapy. The literature on this subject matter raises two main issues of the psychological perspective: the degree of psychological adaptation of an individual to the underwater environment, and the psychophysical condition of a man involved in a specific type of diving and the resulting skills/competences to perform underwater tasks. The article presents selected reports from around the world related to diving psychology resulting from the applied structure/classification of psychological theories, explaining various mechanisms of psychological functioning underwater. The paper presents studies from the perspective of psychodynamics, psychology of health/stress, psychology of individual differences and personality. The main conclusions indicate that in addition to the main problem of an optimal/lack of adaptation of humans to the underwater environment, there is insufficient psychological knowledge (including Polish reports) in the area of personality differences between various types of divers, their social functioning, mental health and psychoeducation with regard to underwater exposures.

Keywords: diving psychology, psychological aspects of diving, psychological adaptation mechanisms in divers.

Celem artykułu jest przegląd literatury pod kątem psychologicznych aspektów nurkowania. Uzyskaną wiedzę można aktualnie zakwalifikować do różnych działów psychologii stosowanej oraz medycyny podwodnej, sportowej, psychiatrii i psychoterapii.

W literaturze przedmiotu w perspektywie psychologicznej podnoszone sa dwa główne zagadnienia: stopień psychologicznych zdolności adaptacyjnych jednostki do środowiska podwodnego oraz kondycja psychofizyczna człowieka w określonym rodzaju nurkowania i wynikające z tego umiejętności/kompetencje do wykonywania zadań pod wodą. W artykule przedstawiono wybrane światowe doniesienia, związane $z$ psychologią nurkowania, wynikające z zastosowanej struktury/ klasyfikacji teorii psychologicznych, wyjaśniających różnorodne mechanizmy psychologicznego funkcjonowania pod woda. Przedstawiono badania w perspektywie psychodynamicznej, psychologii zdrowia/stresu, psychologii różnic indywidualnych i osobowości. Główne konkluzje wskazuja, że obok głównej problematyki optymalnego/lub nie przystosowania człowieka do środowiska podwodnego, istnieje niedosyt wiedzy psychologicznej (w tym doniesień polskich) w zakresie: osobowościowych różnic pomiędzy typami nurków, ich społecznego funkcjonowaniu, psychoprofilaktyki i psychoedukacji przy ekspozycji podwodnej

Słowa kluczowe: psychologia nurkowania, psychologiczne aspekty nurkowania, psychologiczne mechanizmy adaptacyjne nurka.

ARTICLE INFO

PolHypRes 201 Vol. 62 Issue 1 pp. 43 - 54

ISSN: 1734-7009 elSSN: 2084-0535

DOI: 10.2478/phr-2018-0003

Pages: 12 , figures: 0 , tables: 0

page www of the periodical: www.phr.net.pl

Publisher

Polish Hyperbaric Medicine and Technology Society
Typ artykułu: przeglądowy

Rewiev article

Termin nadesłania: 14.12.2017

Termin zatwierdzenia do druku: 03.02.2018 
Целью статьи является обзор литературы по психологическим аспектам ныряния. Полученные знания в настоящее время можно отнести к различным направлениям практической психологии, подводной и спортивной медицины, психиатрии и психотерапии.

В литературе предмета в психологической перспективе поднимаются два основных вопроса: степень психологических адаптивных способностей личности к подводной среде, а также психофизическое состояние человека при определенном роде ныряния и вытекающие из этого навыки/компетенции для выполнения задач под водой. В статье представлены отдельные мировые сведения, связанные с психологией ныряния, вытекающие из использованной структуры/классификации психологических теорий, поясняющих различные механизмы психологического функционирования под водой. Представлены исследования в психодинамической перспективе психологии здоровья/стресса, психологии индивидуальных различий и личности. Основные выводы указывают, что наряду с главной проблематикой оптимальной/или неприспособленности человека к подводной среде, существует недостаток психологических знаний (в том числе польских источников) в области личностных различий между типами ныряльщиков, их социального функционирования, психопрофилактики и психопросвещения при подводном погружении.

Ключевые слова: психология ныряния, психологические аспекты ныряния, психологические адаптационные аспекты ныряльщика

Dieses Artikels ist es, die Literatur im Hinblick auf die psychologischen Aspekte des Tauchens zu untersuchen. Der verfügbare Wissensstand kann derzeit für verschiedene Fachbereiche der angewandten Psychologie sowie der Unterwassermedizin, Sportmedizin, Psychiatrie und Psychotherapie qualifiziert werden.

In der sachbezogenen Literatur werden unter psychologischen Gesichtspunkten zwei Hauptfragen aufgeworfen: der Grad der psychologischen Anpassungsfähigkeit des Individuums in der Welt unter Wasser sowie der psychisch-physische Zustand des Menschen bei einer bestimmten Art des Tauchens und die darauf folgenden Fähigkeiten / Kompetenzen zur Ausführung von Aufgaben unter Wasser. In dem Artikel werden global ausgewählte Informationen im Rahmen der Tauchpsychologie vorgestellt, die sich aus der angewandten Struktur / Klassifikation in der psychologischen Theorie ergeben, einer Theorie also, welche die verschiedenen Mechanismen psychologischer Funktionsmechanismen unter Wasser erklären. Vorgestellt werden Untersuchungen aus psychodynamischer, stress- und gesundheitspsychologischer, individuell-psychologischer und persönlichkeitsbezogener Sicht. Die wesentlichen Schlussfolgerungen weisen darauf hin, dass neben der Hauptfrage des für die Unterwasserwelt optimal / nicht entsprechend angepassten Menschen existiert ein Mangel an psychologischem Wissen (darunter auch Informationen aus Polen) im Bereich: Persönlichkeitsunterschiede zwischen verschiedenen Tauchern, ihre soziale Funktion, Psychoprophylaxe und Psychoedukation unter Wasser.

Schlüsselwörter: Psychologie des Tauchens, psychologische Aspekte des Tauchens, psychologische Anpassungsmechanismen des Tauchers.

El objetivo del artículo es revisar la literatura desde el punto de vista de los aspectos psicológicos del submarinismo. En la actualidad, los conocimientos adquiridos pueden cualificarse en varios departamentos de psicología aplicada y medicina subacuática, medicina deportiva, psiquiatría y psicoterapia. En la literatura sobre el asunto se plantean dos cuestiones principales desde la perspectiva psicológica: el grado de capacidad de adaptación psicológica del individuo al medio subacuático y la condición psicofísica del ser humano en un tipo específico de submarinismo y la habilidad/competencia resultante para realizar tareas bajo el agua. El artículo presenta una selección de informes mundiales relacionados con la psicología del submarinismo, resultantes de la estructura/clasificación aplicada de las teorías psicológicas, explicando varios mecanismos de funcionamiento psicológico bajo el agua. La investigación se presenta en perspectiva psicodinámica, psicología de la salud/estrés, psicología de las diferencias individuales y de la personalidad. Las principales conclusiones indican que, aparte del problema principal de la adaptación óptima y/o no adaptativa de los seres humanos al medio submarino, existe una falta de conocimientos psicológicos (incluidos los informes polacos) en el ámbito de las diferencias de personalidad entre los tipos de buceadores, su funcionamiento social, la psicoprofilaxis y la psicopedagogía durante la exposición submarina.

Palabras clave: psicología del submarinismo, aspectos psicológicos del submarinismo, mecanismos de adaptación psicológica del buzo 


\section{WSTĘP}

Przegląd literatury psychologicznej na temat psychologicznych aspektów nurkowania, doprowadza do kilku wniosków. Po pierwsze problematyka ta rozproszona jest w różnych tematach psychologicznych: psychologii: poznawczej [1], osobowości [2], różnic indywidualnych [3,4], klinicznej [5], pracy [25] i sportu $[6,7]$. Rozważania psychologiczne mieszczą się również w granicach medycyny podwodnej [8], sportowej [9], psychiatrii [10] i psychoterapii [11]. Nurkowanie w literaturze psychologicznej dotyczy głównie: stopnia psychologicznych zdolności adaptacyjnych jednostki do środowiska podwodnego, jej kondycji psychofizycznej w określonym rodzaju nurkowania wraz jej umiejętnościami/kompetencjami do wykonywania określonych zadań pod wodą [2].

Po drugie, należy zauważyć, że o ile wiedza na temat zmian fizjologicznych i problemów medycznych nurka wydaje się być już ugruntowana w perspektywie nauk medycznych, o tyle, $\mathrm{w}$ aspekcie psychologicznym nadal trwają poszukiwania empiryczne, mające na celu ustalenie $\mathrm{z}$ jednej strony, rodzaju mechanizmów regulujących optymalne funkcjonowanie jednostki $\mathrm{w}$ podwodnym środowisku, $\mathrm{z}$ drugiej znalezienie czynników ryzyka doprowadzających do wypadku nurkowego.

Dane badawcze doprowadzają do tezy, że bez względu na rodzaj nurkowania, środowisko podwodne jest bardzo niekorzystne dla psycho-fizjologicznej działalności jednostki $[12,13]$. Z powodu wielu obligatoryjnych nacisków związanych $\mathrm{z}$ ekspozycją podwodną, nurek musi charakteryzować się potwierdzonymi psycho-fizycznymi i fizjologicznymi cechami, aby bezpiecznie funkcjonować w tym wyjątkowym środowisku [14]. Obok tych ważnych dyspozycji zwraca się również uwagę $w$ literaturze przedmiotu na dalsze problemy psychologiczne, wynikajace $\mathrm{z}$ rodzaju nurkowania, które dana osoba wybiera, podejmując określone działania $\mathrm{w}$ przestrzeni podwodnej: a) nurkowanie wojskowe, (b) nurkowanie komercyjne; (c) nurkowanie naukowe i techniczne; (d) nurkowanie półprofesjonalne; i (e) nurkowanie rekreacyjne (sportowe)[14].

Dla przykładu nurkowie służb mundurowych muszą początkowo spełniać surowe normy fizyczne, aby pełnić służbę żołnierską, a następnie bardziej rygorystyczne standardy dotyczące statusu oficerskiego. Dodatkowo muszą dostosować się do statusu nurka wojskowego, który pracuje w warunkach bojowych, w niebezpiecznych sytuacjach, takich jak: ratownictwo na otwartym morzu, unieszkodliwianie środków wybuchowych, tajne operacje czy opuszczanie uszkodzonego okrętu podwodnego. Z psychologicznego punktu widzenia ważnym ograniczeniem wydaje się być brak możliwości wyboru, czy indywidualnej kontroli nad wykonywaniem powierzonych zadań i obowiązków, które zawsze podlegają decyzji dowództwa [15].

Chociaż kryteria wyboru do zatrudnienia w nurkowaniu komercyjnym są równie surowe jak $\mathrm{w}$ nurkowaniu wojskowym, nie tylko $\mathrm{z}$ powodu niebezpiecznych prac podwodnych, nurkowie komercyjni doświadczyć mogą dodatkowego obciążenia psychicznego z powodu sporu sądowego, w sytuacji występujących urazów odniesionych w trakcie pracy. Poważne obrażenia

\section{INTRODUCTION}

A review of psychological literature on the psychological aspects of diving leads to several conclusions. First of all, this topic is dispersed across various psychological issues within psychology, these being: cognitive [1], personality [2], individual differences $[3,4]$, clinical [5], work [25] and sports psychology [6,7]. Psychological considerations also fall within different topics of medicine, such as underwater medicine [8], sports medicine [9], psychiatry [10] and psychotherapy [11]. In psychological literature diving is mainly concerned with: the degree of psychological adaptation of an individual to the underwater environment, their psychophysical condition in a specific type of diving, along with their skills / competences to perform specific tasks under water [2].

Secondly, it should be noted that while the knowledge of physiological changes and medical problems of a diver seem to be already well-established in the perspective of medical sciences, in the psychological aspect, empirical research is still underway and is aimed, on the one hand, at determining the type of regulatory mechanisms ensuring the optimal functioning of an individual in the underwater environment, and, on the other, at finding the risk factors leading to a diving accident.

The research data leads to the thesis that regardless of the type of diving, the underwater environment is highly unfavourable for the psychophysiological activity of an individual $[12,13]$. Due to the many obligatory pressures associated with an underwater exposure, the diver needs to possess specified psycho-physical and physiological traits in order to safely operate in this unique environment [14]. Apart from these important dispositions, attention is also paid to further psychological problems resulting from the type of diving that a given person chooses to perform in order to carry out specific activities in the underwater space: a) military diving, (b) commercial diving; (c) scientific and technical diving; (d) semi-professional diving; and (e) recreational (sports) diving [14].

For example, divers of uniformed services must initially meet strict physical standards in order to perform military service, followed by even more stringent standards regarding the status of an officer. In addition, they need to adapt to the status of a military diver working in combat conditions, dangerous situations, such as open-sea rescue operations, neutralisation of explosives, covert operations or evacuation from a damaged submarine. From the psychological point of view, an important limitation seems to be the lack of choice or individual control over the performance of assigned tasks and duties, which are always subject to the decision of the command [15].

Although the selection criteria for commercial diving are as strict as in military diving, not only because of the danger related to underwater works, commercial divers may experience an additional mental burden related to possible litigation in the case of injuries sustained during work. Serious injuries to commercial divers are extremely costly for the employer, which is why "zero defect" is the main requirement when choosing candidates $[16,55]$.

Recreational diving can be defined as an activity 
nurków komercyjnych są wyjątkowo kosztowne dla pracodawcy dlatego też "zero defektu" to dyktum przy wyborze nurków komercyjnych [16,55].

Rekreacyjne nurkowanie można zdefiniować jako działanie dla przyjemności [17]. Nurkowie rekreacyjni zwiedzający jaskinie lub wraki statków, często przekraczają limity głębokości [17]. Uprawianie nurkowania jako sportu rekreacyjnego poprawia nastrój u osób podejmujących taką aktywnością fizyczną, wykonywaną w okresie wakacyjnym. Korzyści psychologiczne i zdrowotne wynikające $\mathrm{z}$ nurkowania rekreacyjnego wydają się być większe niż praktyka innych sportów w zmniejszaniu stresu i poprawie samopoczucia $[18,19]$.

Wiedza uzyskana z badań na temat nurkowania sportowego pokazuje następny fakt, że optymalne funkcjonowanie człowieka w trakcie takiego nurkowania charakteryzuje się przez jego fizyczną zdolność do długotrwałego wysiłku o średnim natężeniu $\mathrm{z}$ koniecznością prawidłowej równowagi mentalnej aktywności, koncentracji i rozluźnienia [20]. Brak uzyskania powyższych kryteriów oznacza nie tylko konsekwencje natury psychicznej, ale również wysokie ryzyko dla zdrowia człowieka [21,22,23]. Z psychologicznego punktu widzenia wskazuje się też na rolę wytrzymałości emocjonalnej w warunkach ekstremalnych. Brak takiej dyspozycji może doprowadzić do nieefektywnego działania $\mathrm{w}$ wodzie, wystąpieniem chorób oraz wypadków nurkowych[24].

Jak już wspomniano, w organizmie nurka pod wodą występują zmiany fizjologiczne i korespondujące z nimi zmiany psychologiczne, a ich wielkość zależna jest także od czynników neuropsychicznych i dyspozycji psychosomatycznych nurka [12]. Współzależność ta wiąże się również $\mathrm{z}$ indywidualnym doświadczeniem w nurkowaniu. Brak wcześniejszej praktyki nurkowej przyczynia się do obniżenia progu odporności emocjonalnej w wodzie [26].

Odporność psychiczna nurka zależy także od jego psychologicznych indywidualnych właściwości: cech osobowości, osobniczego stylu działania, zasobów i sprawności przebiegu procesów poznawczopercepcyjno-motorycznych oraz poziomu motywacji $[17,27]$. Wraz $\mathrm{z}$ dysonansem między wymaganiami i zadaniami, które pojawiają się przed nurkiem w środowisku podwodnym, a poziomem wydolności psychofizycznej, intensyfikuje się obciążenie psychiczne.

W nurkowaniu "technicznym” jedną z ważniejszych dyspozycji psychologicznych jest wysoki poziom sprawności manualno-operatorskiej, który wraz odpornością psychiczną staje się niezbędny podczas wykonywania skomplikowanych zadań, realizowanych po wodą. Działania w tak obciążających ludzkie zmysły warunkach, wymagają od nurka dokonywania automatycznych wyborów, podejmowania szybkich decyzii, czy najlepszych bądź jedynie możliwych do realizacji sposobów wykonania zadania [15].

Wyuczone podczas treningów wzorce zachowań i opanowane schematy postępowania, muszą być zastosowane w ekspozycji podwodnej w taki sposób, aby efektywnie zrealizować wyznaczone cele. W sytuacji przeciążenia psychofizycznego pod wodą, najczęściej obniża się sprawność działania nurka i popełniania on wówczas przez błędy w realizacji kolejnych, cząstkowych sekwencji zadania $[28,55]$.

Aktualnie, w celu poprawy kondycji psychomotorycznej (a tym samym w celu uzyskiwania taken up for pleasure [17]. Recreational divers visiting caves or shipwrecks often exceed regular depth limits [17]. Practising diving as a recreational sport improves the mood of people undertaking such a physical activity during the holiday season. The psychological and health benefits of recreational diving tend to surpass those resulting from practising other sports when it comes to stress reduction and improving one's well-being $[18,19]$.

Knowledge gained from research on sports diving indicates the next fact that the optimal human functioning during such an activity understood as a person's physical capability of undertaking a long-term effort of medium intensity involves the necessity to maintain balance between mental activity, concentration and relaxation [20]. Failure to achieve the above criteria not only has psychological consequences, but also a high risk to human health $[21,22,23]$. From the psychological point of view, the role of emotional endurance in extreme conditions is also indicated. An absence of such dispositions may result in inefficient operation in the water, an occurrence of various conditions and diving accidents [24].

As has already been mentioned, physiological changes along with corresponding psychological ones occur in the diver's body while under water, and the size of these changes depends on neuropsychological factors and the diver's psychosomatic dispositions [12]. This correlation is moreover associated with an individual diving experience. A lack of previous diving practice contributes to the lowering of the threshold of emotional resilience in water [26].

Furthermore, the diver's mental resilience depends on the individual's psychological properties: personality traits, individual style of action, resources and efficiency of cognitive-perceptual-motor processes, and the level of motivation $[17,27]$. The maintained strain is intensified with the dissonance between the requirements and tasks that the diver needs to face in the underwater environment, and his level of psychophysical efficiency.

One of the most important psychological dispositions in 'technical' diving is the high level of manual and operational skills, which together with psychological resilience becomes indispensable while performing complicated tasks under water. Activities undertaken in conditions having such a burdening effect on human senses, require the diver to make automatic choices, quick decisions, or choose the best or only possible ways to accomplish the task [15]. The behavioural patterns and procedures learned during training must be applied during an underwater exposure in such a way as to effectively achieve the set goals. In the situation of a psychophysical overload under water, the diver's efficiency is most often degraded which leads to mistakes in the implementation of consecutive partial task sequences $[28,55]$.

Currently, in order to improve the psycho-motor condition (and thus obtain optimal adaptation to the conditions of operation in the underwater environment), simulated procedures are used to enable the creation of very diverse, extreme conditions that may occur in the underwater environment. Simulators performing several important functions, among which are the ones that improve the motivational and emotional functions (increase the diver's resilience in extreme situations) and optimise the level of stress the diver can cope with seem to be important from the psychological perspective 
optymalnej adaptacji do warunków działania $\mathrm{w}$ środowisku podwodnym) wykorzystywane są procedury symulacyjne, umożliwiające wykreowanie bardzo różnorodnych, ekstremalnych warunków, które mogą wystąpić w podwodnym środowisku. Symulatory spełniają kilka ważnych funkcji, wśród których ważne z psychologicznej perspektywy wydają się te poprawiające funkcje motywacyjne i emocjonalne nurka (zwiększa się odporność na sytuacje ekstremalne) oraz optymalizujące poziom radzenia sobie ze stresem $[12,29]$.

W podejmowanej psychologicznej problematyce na temat nurkowania osobną kwestią mieszczącą się $\mathrm{w}$ zakresie psychologii klinicznej i psychiatrii stanowi doświadczenie lęku. Zagadnienie to rozpatrywane jest w trojakim znaczeniu. Główną przyczyną choroby dekompresyjnej i urazu ciśnieniowego płuc u nurków jest gwałtowne wynurzenie, którego głównym bodźcem jest doświadczenie lęku panicznego [30]. Ponadto, najprawdopodobniej obiektywna miara lęku-cechy może być skuteczna w przewidywaniu występowania lęku panicznego pod wodą [31]. Wreszcie wyniki badań wskazują, że podwodna trauma ma zarówno ostre, jak i trwałe konsekwencje behawioralne, $w$ tym zaburzenia lękowe, które omawiane sa w literaturze $\mathrm{w}$ odniesieniu do ich znaczenia dla powstawania stresu i PTSD [32,33].

Podsumowując, opisane dotychczas
w literaturze psychologiczne problemy nurka, podnoszą kwestie nabywania przez niego pewnych cech szczególnego przystosowania do nowych warunków. Wiadomo już dzisiaj, że powtarzane narażanie człowieka na działanie niezwykłych dlań warunków środowiska podwodnego, poszerza granice adaptacji do tego środowiska, ale rodzi też problemy. Uzyskana dzięki nim wiedza przyczyniła się do rozwoju dziedziny psychologicznej, którą dla celów artykuły nazwano „psychologią nurkowania”.

\section{PRZEGLĄD BADAŃ W WYBRANYCH ASPEKTACH PSYCHOLOGII NURKOWANIA}

Aktualnie posługiwanie się pojęciem „psychologia nurkowania” może nosić znamiona pewnego nadużycia teoretycznego, albo praktycznego, bowiem $\mathrm{w}$ polskiej psychologicznej literaturze przedmiotu oraz w przestrzeni akademickiego kształcenia psychologów, brakuje większego zainteresowania tą problematyką. Obszar psychologii nurkowania stanowi kolokwialnie rzecz ujmując, niszę dla niewielu badaczy zainteresowanych tymi zagadnieniami, które mieszczą się w zakresie psychologii morskiej, podejmującej się wyjaśnienia interakcji między psychologią i różnymi dziedzinami świata morskiego [55].

W pewnym jednak optymistycznym ujęciu należy stwierdzić, że w literaturze światowej pojawiają się nieco częściej doniesienia dotyczące problematyki funkcjonowania psychicznego osób nurkujących i być może, jest to nieco nadmiarowe stwierdzenie, ale ukonkretnia się coraz mocniej nowa subdyscyplina psychologiczna - psychologia nurkowania.

W dużej mierze związane jest ze wzrostem liczby osób uprawiających nurkowanie sportoworekreacyjne. Do lat 80-tych taka aktywność była podejmowana przez niewielu sportowców; natomiast obecnie sytuacja zmienia się i sport ten, dzięki rozwojowi sprzętu i nauki, uprawia około milion ludzi na świecie.
$[12,29]$.

In the undertaken psychological discussion on diving, a separate issue within the scope of clinical psychology and psychiatry is connected with the experience of anxiety. This issue is considered in a threefold sense. The main cause of decompression sickness and pulmonary barotrauma in divers is a rapid ascent which is mainly due to the experience of a panic attack [30]. Moreover, it is likely that an objective measure of the anxiety-trait would be effective in predicting panic attacks while underwater [31]. Finally, research results indicate that underwater trauma has both acute and persistent behavioural consequences, including anxiety disorders, which are discussed in literature in relation to their significance for stress formation and PTSD [32,33].

Summing up, the psychological problems in divers described thus far in literature raise issues related to their acquisition of certain traits of a special adaptation to new conditions. It is already known today that repeated exposure of humans to the unusual conditions of the underwater environment, extends the limits of adaptation to this environment but also gives rise to certain problems. The knowledge gained thanks to such exposures contributed to the development of a psychological domain, which for the purposes of the article will be referred to as "diving psychology".

\section{RESEARCH REVIEW IN SELECTED ASPECTS} OF DIVING PSYCHOLOGY

The current use of the term "diving psychology" may bear the characteristics of a certain theoretical or practical abuse, as in the Polish psychological literature of this subject matter, and in the area of academic education of psychologists, there is a lack of interest in this topic. The area of diving psychology is, colloquially speaking, a niche for the few researchers interested in the issues falling within the scope of marine psychology, who endeavour to explain the interactions between psychology and various areas of the marine world [55].

However, it can be optimistically stated that world literature provides an increasing number of reports connected with the mental functioning of divers and, to a certain extent, the new psychological discipline - diving psychology - has become more established.

This is largely related to an increase in the number of people practising sports and recreational diving. Until the 1980s, this activity was undertaken by only a few athletes; whereas now the situation is changing and thanks to the development of equipment and science, it is practised by approximately one million people all over the world. Diving is a form of activity often recommended in mass tourism, which is why we may speak about a growing social practice [34]. On the other hand, many years of observations related to the safety of military and recreational divers have made it possible to see the importance of health / psychological selection of diver candidates and active divers, both military and recreational. [35,36]. The search for personality factors which have a direct impact on the safety of divers, and the problems reported by divers following the completion of a dive, have all helped to explain the causes of incidents occurring under water. As it is known today, these factors have proved to be important for the safety of divers.

Summing up, the increase in interest in 
Nurkowanie jest formą działania często polecaną w turystyce masowej, dlatego też można mówić o wzrastającej w tym obszarze praktyce społecznej [34]. $\mathrm{Z}$ drugiej strony wieloletnie obserwacje związane $\mathrm{z}$ bezpieczeństwem nurkowania $\mathrm{w}$ celach militarnych jak i rekreacyjnych pozwoliły na dostrzeżenie znaczenia selekcji zdrowotnej/psychologicznej kandydatów na nurków i czynnych nurków, zarówno wojskowych jak i rekreacyjnych. [35,36]. Poszukiwanie osobowościowych czynników mających bezpośredni wpływ na bezpieczeństwo nurkowania i problemy nurków zgłoszone po jego zakończeniu, pozwalały wyjaśnić przyczyny incydentów występujących pod wodą. Czynniki, te jak dzisiaj wiadomo okazały się istotne dla bezpieczeństwa nurkujących.

Reasumując, wzrost zainteresowania nurkowaniem rekreacyjnym/sportowym oraz intensyfikacja badań dotyczących bezpieczeństwa człowieka w działaniach podwodnych otworzyły przestrzeń empiryczną dla poszukiwań psychologicznych czynników optymalizujących jego funkcjonowanie pod wodą.

Początek zainteresowań problematyką psychologiczną na temat funkcjonowania człowieka w środowisku podwodnym przypisywany jest Behnke i jego artykułowi „Reakcje psychologiczne i psychiczne w nurkowaniu i podwodnej wojnie (Psychological and psychiatric reactions in diving and submarine warfare) opublikowanemu w 1945 roku przez American Journal of Psychiatry [37]. Autor zwrócił uwagę na fakt obciążeń stresorami i samego stresu u nurków wojskowych w czasie drugiej wojny światowej; podkreślając jako stresory: przedłużone okresy czasu bez możliwości odpowiedniego odpoczynku i relaksu, działania w skomplikowanym sprzęcie technicznym, w ekstremalnych temperaturach, brak snu, hałas i wibracja.

Przegląd psychologicznych doniesień badawczych i rozważań teoretycznych na temat nurkowania, wynika w dalszej części artykułu, z zastosowanej tu struktury/klasyfikacji teorii psychologicznych, które dla poszczególnych autorów, stanowiły bazę wyjaśniającą różnorodne mechanizmy psychologicznego funkcjonowania przy ekspozycji podwodnej.

Wykorzystując koncepcję psychologii głębi z tkwiącymi w nieświadomości człowieka popędami i konfliktami Sessa, Pallotta i Fati [38] odkryli w swoich badaniach, że powody, które skłaniają jednostkę do uprawiania nurkowania, pochodzą z jej nieświadomych pokładów psychicznych. W sytuacji przekraczania przez nurka linii między powietrzem i wodą, zdaniem badaczy, pojawia się przepaść między głębokimi nieświadomymi popędami a świadomymi motywacjami. W 1968 Tatarelli [39] stwierdził, że "zdystansowana, zamknięta w sobie osoba" nie nadaje się do nurkowania, ponieważ "stłumione jej cechy moralne" mogą okazać się szkodliwe i niebezpieczne w działaniu podwodnym. Odone i inni [40] poprzez stworzone grupy dyskusyjne nurków i ich trenerów, próbowali wykryć psychodynamiczne podstawy podwodnej psychologii.

Zdaniem autorów niezbędne było zrozumienie mechanizmów psychodynamicznych istniejących w podwodnej działalności nurków i zastosowanie ich $\mathrm{w}$ metodach dydaktycznych. Autorzy przeanalizowali techniki stosowane w nauczaniu nurkowania, a zwłaszcza te dotyczące jego bezpieczeństwa. Badacze uważali, że recreational/sports diving and the intensification of research regarding human safety in underwater activities has opened an empirical space for the search of psychological factors that optimise human functioning under water.

The onset of interest in the psychological aspect of human functioning in the underwater environment is attributed to Behnke and his article Psychological and psychiatric reactions in diving and submarine warfare published in 1945 by the American Journal of Psychiatry [37]. The author points out the fact that military divers were burdened with stressors and stress itself during World War Two; the said stressors include: extended periods of time without the possibility of having adequate rest and relaxation, operation of complicated technical equipment, extreme temperatures, lack of sleep, noise and vibration.

A review of psychological research and theoretical considerations on diving resulted in the following part of the article from the applied structure/classification of psychological theories, which served as the basis for particular authors for finding an explanation of various mechanisms of psychological functioning during an underwater exposure.

Using the concept of psychology of depth with a man's instincts and conflicts rooted in the unconscious, Sessa, Pallotti and Fati [38] found in their research that the reasons leading an individual towards taking up diving originate in the unconscious layers of the psyche. In the situation when the diver crosses the line between the air and water, according to the researchers, there is a chasm between one's deep unconscious drives and conscious motivations. In 1968 Tatarelli [39] stated that "a distant, introverted person" is not suitable as a diver because the "suppressed moral traits" can be harmful and dangerous in an underwater operation. In the formed discussion groups of divers and their trainers Odone et al. [40] tried to discover the psychodynamic basis of underwater psychology. According to the authors, it was necessary to understand the psychodynamic mechanisms existing in the underwater activity of divers and apply them in didactic methods.

The authors analysed the techniques used in teaching diving, especially those concerning its safety. Researchers believed that most accidents are not accidental but result from the unconscious willingness to take risks. Therefore, they made an attempt to understand the psychodynamics of this problem. The results of their research indicate that it is important to treat the teaching methods in diving not only as a means of passing on useful skills and knowledge, but also as a psychotherapeutic technique that helps the diver control any sort of self-destructive aggressive inclinations.

In 1985, using psychodynamic theory for their considerations, Spigolon and Dell'oro [41] found that autogenic training could be useful for divers in improving their mental condition. According to researchers, learning of this technique helped in fact to break the negative circle, starting from the diver's troublesome situation under water up to the occurrence of a panic attack.

The results of their research also show that in autogenous training, certain body positions depend on whether the diver is in a state of apnea or oxygenation. Certain positions may also prevent muscle relaxation, which is necessary for maintaining the optimal psychophysiological balance under water. It is also worth 
większość wypadków nie jest przypadkowa, ale wynika $\mathrm{z}$ nieświadomych chęci podejmowania ryzyka. Zatem podjęli oni próbę zrozumienia psychodynamiki tego problemu. Wyniki ich badań wskazują, że ważne jest, aby traktować metody nauczania $\mathrm{w}$ nurkowaniu, nie tylko jako środek do przekazywania użytecznych umiejętności i wiedzy, ale także jako technikę psychoterapeutyczną, pomagającą nurkowi kontrolować wszelkie autodestrukcyjne agresywne popędy.

W 1985 roku Spigolon i Dell'oro [41] używając teorii psychodynamicznej dla swoich rozważań, stwierdzili, że trening autogenny może być przydatny dla nurka w poprawie jego kondycji psychicznej. Poznanie tej techniki pomogło $\mathrm{w}$ rzeczywistości, pozwolić zdaniem badaczy, na przełamanie negatywnego kręgu, zaczynającego się od kłopotliwej sytuacji nurka pod wodą i nakręcającego się, aż do występującego u niego ataku paniki.

Wyniki ich badań pokazują ponadto, że w treningu autogennym określone pozycje ciała zależą od tego, czy nurek znajduje się w stanie bezdechu czy utlenowania. Pewne pozycje mogą również zapobiegać relaksacji mięśni, co jest konieczne dla optymalnej równowagi psychofizjologicznej pod wodą. Warto również wspomnieć o pracach Jennifer Hunt [42]. Wykorzystała ona analizę psychoanalityczną do opisania działania związanego z ryzykiem i wypadkami nurkowymi.

Autorka zbadała nieświadome konflikty, które zdawały się zwiększać zaangażowanie nurka podczas nurkowania $\mathrm{w}$ głębokim zanurzeniu, prowadzące go niemal do śmiertelnego wypadku. Jej badania opierały się na wywiadach $\mathrm{z}$ osobami uprawiającymi nurkowanie rekreacyjne i techniczne. Według badaczki zaangażowanie mężczyzn w konkretny zawód, sport lub rekreację często zakorzenione jest we wczesnym dzieciństwie.

Zainteresowanie nurków sportowych wodą, łodziami lub nurkowaniem zwykle rozpoczyna się $\mathrm{z}$ pewnym opóźnieniem $\mathrm{w}$ rozwoju osobniczym, ale nurkowanie $\mathrm{z}$ głębokim zanurzeniem staje się specjalną areną, na której niektórzy mężczyźni wydają się podejmować i próbować opanowywać konflikty zakorzenione we wczesnych doświadczeniach z nieobecnymi i wykorzystującymi ojcami.

Istnieją również przesłanki świadczące o tym, że nurkowie i elitarni sportowcy, zaangażowani w sporty wysokiego ryzyka, mają pewne wzorce rodzicielstwa i mogą realizować podobne fantazje. Im bardziej ryzykowny i gwałtowny jest sport, tym bardziej prawdopodobne jest, że kwestia biseksualizmu, męskości, agresji i sadomasochizmu wydaje się wpływać na ten indywidualny wybór dziedziny sportowej.

Jednym z ważniejszych obszarów psychologicznych dostarczających inspiracji teoretycznych do badania adaptacji osób nurkujących do środowiska podwodnego stały się ustalenia w ramach psychologii zdrowia, w tym stresu psychologicznego osób nurkujących w niebezpiecznych sytuacjach w środowisku podwodnym [20].

Ustalenia badaczy są jednoznaczne i wskazujące, że stres wywołany ekstremalnym środowiskiem. jak w przypadku nurkowania w głębinach z wysokim ciśnieniem atmosferycznym, wywołuje zmiany zarówno w ciele, jak i w psychice $[15,16,45,46,47]$.

Dla przykładu, ustalono, że pamięć przestrzenna zostaje znacznie upośledzona przy kompresji pomiędzy mentioning the works of Jennifer Hunt [42]. She used psychoanalysis to describe the mechanism associated with the risk and diving accidents. The author examined unconscious conflicts that seemed to increase during deep diving, leading divers almost to a fatal accident. Her research was based on interviews with people practising recreational and technical diving.

According to the researcher, the involvement of men in a particular profession, sport or form of recreation is often rooted in early childhood. The interest of sport divers in water, boats or scuba diving usually starts with a certain delay in individual development, and deep diving constitutes a special arena where some men seem to overcome the conflicts rooted in their early experiences related to absent or abusive fathers. There are also indications that divers and elite athletes involved in high-risk sports follow certain parenting patterns and may pursue similar fantasies. The more risky and violent the sport is, the more likely it is that the issue of bisexuality, masculinity, aggression and sadomasochism influences such an individual choice of a sports discipline.

One of the most important psychological areas providing theoretical inspirations to study the adaptation of divers to the underwater environment are the findings of health psychology, including psychological stress of people performing dives in dangerous situations [20].

Researchers' findings are unambiguous, and indicative of stress caused by an extreme environment as in the case of diving to greater depths, subjecting the diver to high pressure causing changes both in the body and in the psyche $[15,16,45,46,47]$. For example, it has been determined that spatial memory is significantly impaired with compressions performed between 410 and $480 \mathrm{~m}$, showing a large individual variability. Research also revealed a reduced visual spatial ability during diving at 300-540 $\mathrm{m}$ [44].

In the theoretical psychological perspective regarding the constancy of personality traits, there are research reports on the personality traits and attitudes of divers in the underwater environment. In their research, Griffiths, Steel, Vaccaro and Karpman [48] examined the diver's anxiety and the correlation between relaxation and diving techniques. However, the main issue consisted in providing descriptions of the psychological profiles of divers in order to determine the personality risk factors of underwater accidents. [49].

In their book titled Stress and performance in diving Bachrach and Egstrom explained the role of individual differences in the adaptation of military personnel to a stressful environment, taking into account the existing models of intelligence, personality and performance. Among others, in the sample of professionals $(\mathrm{N}=575)$ a direct and positive relationship between emotional adjustment, conscientiousness and general mental abilities in relation to underwater adaptation, as well as the negative correlation with emotional reactivity were determined.

The conclusions from the research suggest that the optimal personality profile of the diver should be characterised by an ability to function effectively in the conditions of stress and crisis, as well as cope with stress using a cognitive-behavioural strategy. It should be characterised by a high emotional control, with a high level of error control and avoiding high risk levels.

From the point of view of an overall performance model, professional divers should, on the one hand, perform dives with the use of equipment, 
410 a 480 m, wykazując dużą indywidualną zmienność. Badania ujawniły również zmniejszoną wizualną zdolność przestrzenną podczas nurkowania na 300-540 m [44].

W teoretycznej psychologicznej perspektywie dotyczącej stałości cech osobowości, istnieją doniesienia badawcze na temat cech osobowości i postaw nurka w środowisku podwodnym. W swoich badaniach Griffiths, Steel, Vaccaro i Karpman, [48] zbadali niepokój nurka i korelację pomiędzy technikami relaksacyjnymi i nurkowymi. Jednak głównym zagadnieniem w tym temacie było opisanie profili psychologicznych nurków w celu ustalenia osobowościowych czynników ryzyka wypadków podwodnych [49].

W swojej książce Bachrach i Egstrom, Stress and performance in diving badacze wyjaśnili wkład indywidualnych różnic $\mathrm{w}$ adaptację personelu wojskowego do stresującego środowiska, biorąc pod uwagę istniejące modele inteligencji, osobowości i wydajności. Ustalono między innymi w próbie profesjonalistów $(\mathrm{N}=575)$ bezpośredni dodatni związek dopasowania emocjonalnego, sumienności i ogólnej zdolności umysłowej $\mathrm{z}$ podwodną adaptacją, a także ujemną korelację z reaktywnością emocjonalną.

Wnioski z badań sugerują, że optymalny profil osobowościowy nurka powinien charakteryzować się zdolnością do skutecznego działania $w$ warunkach stresu i sytuacji kryzysowych i radzeniem sobie ze stresem poprzez strategię poznawczo-behawioralną. Powinna cechować go wysoka kontrola emocjonalna, przy jednocześnie dużej kontroli błędów i unikaniu wysokiego poziomu ryzyka

Z punktu widzenia ogólnego modelu wydajności, profesjonalni nurkowie powinni $\mathrm{z}$ jednej strony, nurkować przy użyciu sprzętu, korzystać z narzędzi pneumatycznych i hydraulicznych, sprawdzać i naprawiać uszkodzenia w kadłubie okrętów. Te wymiary wydajności reprezentują umiejętności, które wynikają z psychologicznych kompetencji takich jak: krytyczne myślenie, ocena $\mathrm{w}$ podejmowaniu decyzji, analiza problemu i rozkładu czasu, rozumienie ustne i pisemne, rozumowanie dedukcyjne i indukcyjne, selektywna uwaga, orientacja przestrzenna, siła statyczna i dynamiczna, sprawność manualna i wielokrotna koordynacja.

W optymalnym osobowościowym profilu nurka powinny znaleźć się takie cechy jak: zarządzanie lękiem i stresem, odpowiedzialność, autonomia działania i zdolność wysiłkowa [50]. Z badań Nevo i Breitsteina [20] wynika, że nurkowie $\mathrm{w}$ porównaniu $\mathrm{z}$ osobami nienurkującymi, charakteryzują się większą motywacją do ryzyka i przygody, wyższym poziomem męskości i agresywności, a także mniejszą podatnością lękową oraz są zdrowsi fizycznie.

W badaniach z 2010 roku Coetzee [51] ustalił jakie cechy osobowości są powszechne wśród nurków rekreacyjnych. W badaniu sześćdziesięciu nurków tabele częstotliwości wykazały wysokie wyniki w zakresie samowystarczalności, odwagi i impulsywność oraz niskie w zakresie zgodności, ciepła i wrażliwości. Wyniki tego badania pokazały, że cechy osobowości nurków różnią się od tego, co wskazano w literaturze, jako typowy profil osobowości ekstremalnego sportowca.

Przeprowadzona eksploracyjna analiza czynnikowa pokazała cztery typy osobowości nurków rekreacyjnych: poszukiwacz przygód, racjonalista, marzyciel i pasywno-agresywny typ nurka, zidentyfikowano z macho. Wyniki tych badań sugerują, że pneumatic and hydraulic tools, inspect and repair damage to the hulls of ships. These performance dimensions represent skills that result from such psychological competences as: critical thinking, judgment in decision making, problem and time distribution analysis, oral and written understanding, deductive and inductive reasoning, selective attention, spatial orientation, static and dynamic force, dexterity and multiple coordination.

The optimal personality profile of a diver should include such features as: management of anxiety and stress, responsibility, autonomy of action and physical capacity [50]. The research carried out by Nevo and Breitstein [20] shows that divers are more motivated towards risk and adventure, demonstrate a higher level of masculinity and aggressiveness, as well as are less susceptible to anxiety, and are physically healthier. In a 2010 study, Coetzee [51] determined which personality traits are common among recreational divers. In a study of sixty divers the obtained frequency tables showed high results in terms of self-sufficiency, courage and impulsivity whereas low scores in relation to conformity, warmth and sensitivity. The results of this study proved that the personality traits of divers differ from what is indicated in the literature as a typical personality profile of an extreme athlete.

An exploratory factor analysis showed four types of personality of recreational divers: an adventurer, a rationalist, a dreamer and a passive-aggressive diver identified with a macho type. The results of these studies suggest that the number of high-risk behaviours revealed by a diver depends on his personality type.

Van Wijk [4] abandoned the international trend of comparing the personality traits of divers and seafarers and conducted his own research to determine the extent to which the personalities of military and recreational divers differ. By controlling 16 personality factors, examining 28 South African divers, 28 South African seamen, and 28 civilian divers, the researcher determined that navy seafarers qualified as divers achieved higher ego strength scores than seafarers who were not military or civilian divers.

They proved to be more psychologically "tough" and adventurous. Moreover, Navy divers were less assertive, obtained higher scores on the superego scale, were more practical and characterised by a greater wellbeing. Another important psychological research problem within the perspective of clinical psychology are issues concerned with panic fear described in literature as the most frequent cause of death among divers. Morgan [52] examined over 500 experienced recreational divers and discovered that more than half of them experienced panic attacks and that at least one of these attacks took place during dive performance.

The author constructed an anxiety test allowing to identify people with the highest probability of a panic attack before the commencement of a dive. Although there are many factors responsible for injuries and fatal diving accidents, there is a general consensus among researchers that many of them are caused by panic. There is also evidence that people with an elevated level of the anxiety-trait more often demonstrate stronger anxiety reactions when they are exposed to stressors.

Thus, there is a subgroup in the population of divers with an increased level of the risk of accident/death. However, the efforts towards showing that selected interventions such as hypnosis, imaging, meditation and relaxation can reduce stress responses in 
liczba zachowań wysokiego ryzyka ujawnianych przez nurka, zależy od jego typu osobowości.

Van Wijk [4] odstąpił od międzynarodowego trendu porównywania cech osobowości nurków i marynarzy i przeprowadził własne badanie w celu ustalenia, w jakim stopniu różnią się osobowościowo nurkowie wojskowi i rekreacyjni. Kontrolując 16 czynników osobowości, badając 28 nurków z RPA, 28 marynarzy z RPA oraz 28 nurków cywilnych, badacz ustalił, że marynarze marynarki wojennej będący nurkami, osiągnęli wyższe wyniki $\mathrm{w}$ aspekcie siły ego $\mathrm{w}$ porównaniu $\mathrm{z}$ marynarzami nie będący nurkami i nurkami cywilnymi.

Okazali się oni też bardziej „twardzi” psychicznie i żądni przygód. Ponadto, nurkowie marynarki wojennej byli mniej asertywni, uzyskali wyższe wyniki na skali badającej superego, byli bardziej praktyczni i uzyskiwali wyższe samopoczucie.

Kolejnym ważnym psychologicznym problemem badawczym w perspektywie psychologii klinicznej stały się zagadnienia dotyczące lęku panicznego opisywanego w literaturze jako najczęstsza przyczyna zgonów nurków. Morgan [52] przebadał ponad 500 doświadczonych nurków rekreacyjnych i odkrył, że ponad połowa z nich doświadczyła ataków paniki i że przynajmniej jeden $\mathrm{z}$ tych ataków, miał miejsce podczas nurkowania.

Autor skonstruował test na niepokój, dzięki któremu możliwa byłaby identyfikacja osób o największym prawdopodobieństwie ataku paniki, zanim rozpoczęliby nurkowanie. Chociaż istnieje wiele czynników odpowiedzialnych za obrażenia i wypadki śmiertelne w nurkowaniu, istnieje ogólna zgoda wśród badaczy, że wiele $\mathrm{z}$ tych przypadków jest spowodowanych paniką. Istnieją ponadto dowody na to, że osoby charakteryzujące się podwyższonym poziomem lęku-cechy, częściej mają silniejsze reakcje lękowe, gdy są wystawione na działanie stresora.

Zatem istnieje podgrupa $\mathrm{w}$ populacji nurków, u której istnieje zwiększony poziom ryzyka wypadku/śmierci. Wysiłki mające na celu wykazanie, że wybrane interwencje, takie jak hipnoza, obrazowanie, mediacja i relaksacja, mogą zmniejszyć reakcje na stres u lękowych nurków, nie przyniosły jednak konsekwentnych wyników, i w związku z tym istnieje potrzeba systematycznych badań dotyczących skuteczności wybranych strategii interwencji. Próby takiej podjął się Gary Ladd, [11] który w swojej działalności zarówno klinicznej, jak i badawczej wyjaśniał wywoływaną nurkowaniem panikę, podwodne wypadki, a także opracował specyficzne terapie dla osób, które straciły swojego partnera podczas nurkowania.

Van Wijk [3] próbował zbadać i opisać profil zdrowia psychicznego specjalistów $\mathrm{z}$ południowoafrykańskiej marynarki wojennej pracujących $\mathrm{w}$ ekstremalnych środowiskach oraz postawił problem oszacowania występowania wśród nich objawów psychopatologicznych. W badaniach wykorzystano Minesocki Inwentarz Osobowości (MMPI) -2 do określenia głównych wzorców psychopatologii i nieprawidłowego funkcjonowania osobowości. Próbę 161 nurków i 152 marynarzy okrętów podwodnych, porównano z próbką 139 marynarzy marynarki wojennej.

Nurkowie i marynarze okrętów podwodnych wykazywali pożądane profile zdrowia psychicznego, chociaż znaleziono specyficzne dla zawodu markery nietypowych wzorców zachowań, takie jak: nieznacznie podwyższone wyniki w skali hipomanii wśród nurków anxiety divers did not produce consistent results, therefore there is still a need for a systematic research into the effectiveness of particular intervention strategies. Such an attempt was made by Gary Ladd, [11] who in his clinical and research activities explained the divinginduced panic, underwater accidents, as well as developed specific therapies for people who lost their partners during a dive.

Van Wijk [3] attempted to investigate and describe the mental health profile of South African navy specialists working in extreme environments and formulated the problem of estimation of an occurrence of psychopathological symptoms among them. Minnesota Multiphasic Personality Inventory (MMPI) -2 was used in the research to determine the main patterns of psychopathology and personality disorders. A sample of 161 divers and 152 submarine seamen were compared with a sample of 139 navy seamen.

Divers and submarine seamen showed the desired mental health profiles, although professionspecific markers of atypical behavioural patterns were found such as: slightly elevated hypomania scores among divers and responsibility scores of submarine seamen. Moreover, it was established that there is a strong expression of intensification of male gender roles among divers, submarine seamen and naval seamen. The author suggests that in cases when an abnormal dynamics of behaviour occurs, it can be interpreted as adaptive and not psychopathological, as the subjects acted in the specific context of an operational environment.

In summary, from the broad perspective of psychological research and knowledge, the current state of reports and considerations on the psychological aspects of diving is still insufficient. Their main focus is involved with the problem of optimal/or a lack of adaptation of humans to the underwater environment. Despite the important contribution recently made by researchers, there is still a lack of knowledge regarding the psychodynamic mechanisms of this activity; the personality differences between recreational and technical divers have not been studied enough; too little is known about the correlation between extreme sports and diving. The current state of knowledge did not allow for the development of a psychological tool cooperating with medical protocols in the selection of people practising diving both as a sports activity and professionally; the social and psychoeducational aspects that are necessary to take up diving are considered only sporadically and to a very limited extent.

To conclude, we should mention that at present works are being conducted on the development of a theoretical model regarding psycho-social risk factors and the quality of life of military divers, which will be subject to empirical verification. The model is built on two concepts of stress (stress at work - a concept developed by Robert Karaska and Tore Theorella [53], and Lazarus's transactional model of stress [54] - personality factors (sense of stress, sense of effectiveness, coping strategies, neuroticism, extraversion, diligence, openness to experience, and agreeableness, causative and community orientation, propensity to risk, emotion control) and the level of general health and life satisfaction.

The general thesis behind the model of psychosocial risk factors and the quality of life of military divers that will be tested in the future, is that physical and psychosocial risk factors (the discrepancy between conditions and requirements for an individual, and their 
oraz w skali odpowiedzialności wśród marynarzy okrętów podwodnych. Ponadto, ustalono, że istnieje silny wyraz męskiej identyfikacji ról płciowych wśród nurków i marynarzy okrętów podwodnych oraz marynarzy marynarki wojennej. Autor sugeruje, że w przypadkach, w których wystąpiła nietypowa dynamika zachowania, można ją interpretować jako adaptacyjną, a nie psychopatologiczną, bowiem badane osoby działały w specyficznym kontekście środowiska operacyjnego.

Podsumowując, z szerokiej perspektywy badań i wiedzy psychologicznej, aktualny stan doniesień i rozważań na temat psychologicznych aspektów nurkowania jest jeszcze niewystarczający. Główny ich nurt podejmuje problematykę optymalnego/lub nie przystosowania człowieka do środowiska podwodnego.

Pomimo ważnego wkładu ostatnio dokonanego przez badaczy, wciąż jednak istnieje niedosyt wiedzy na temat psychodynamicznych mechanizmów tej aktywności; za mało zostały zbadane różnice osobowościowe pomiędzy nurkami rekreacyjnymi i technicznymi; zbyt mało wiadomo na temat korelacji pomiędzy sportami ekstremalnymi a nurkowaniem. Dotychczasowy stan wiedzy nie pozwolił na stworzenie psychologicznego narzędzia, współpracującego $\mathrm{z}$ protokołami medycznymi w doborze osób, uprawiających nurkowanie zarówno w sporcie, jak i zawodowo; aspekty społeczne i psychoedukacyjne, które są niezbędne do podejmowania nurkowania, są rozpatrywane tylko sporadycznie i w bardzo ograniczonym zakresie.

Tytułem zakończenia należy wspomnieć, że aktualnie prowadzone są prace nad tworzeniem teoretycznego modelu, który zostanie poddany weryfikacji empirycznej, dotyczącego psycho-społecznych czynników ryzyka i jakości życia nurków wojskowych. Model budują dwie koncepcje stresu (stres w pracy Roberta Karaska i Toresa Theorella [53] i transakcyjny model stresu Lazarusa [54] czynniki osobowościowe (poczucie stresu, poczucie skuteczności, strategie radzenia sobie ze stresem, neurotyczność, ekstrawersja, sumienność, otwartość na doświadczenie, oraz ugodowość; orientacja sprawcza i wspólnotowa, skłonność do ryzyka, kontrola emocji) oraz poziom ogólnego stanu zdrowia i zadowolenia z życia.

Ogólna teza w przyszłości testowanego modelu psychospołecznych czynników ryzyka i jakości życia nurków wojskowych głosi, że fizyczne i psychospołeczne czynniki ryzyka (rozbieżność pomiędzy warunkami i wymaganiami stawianymi jednostce, oraz jej subiektywna poznawcza ocena warunków pracy) aktywizują mechanizm powstawania stresu i strategie radzenia sobie $\mathrm{z}$ nim.

Wydaje się, że niektóre $\mathrm{z}$ cech osobowości nurków wojskowych mogą stanowić swoiste czynniki ochronne (resilience) w radzeniu sobie ze stresem, nie mniej długotrwałe narażenie na występujące i subiektywnie ocenione negatywnie psychospołeczne i fizyczne stresory doprowadzić mogą do dysharmonii w ich ogólnym stanie zdrowia. Ponadto wydaje się, że zarówno bezpośrednie strategie radzenia sobie ze stresem oraz kooperujące $\mathrm{z}$ nimi czynniki ochronne i w konsekwencji dobry ogólny stan zdrowia nurków wojskowych warunkuja ich wysoki poziom zadowolenia z życia. subjective cognitive assessment of working conditions) activate the mechanism of formation of stress and coping strategies. It seems that some of the personality traits of military divers may constitute specific protective factors (resilience) in coping with stress, however, a long-term exposure to subjectively negatively evaluated psychosocial and physical stressors may lead to a disharmony in their general health condition. Furthermore, it seems that both the direct coping strategies, the concurrent protective factors and, consequently, the good overall health of military divers determine the high level of their life satisfaction. 


\section{REFERENCES}

1. Hemelryck W, Germonpré P, Papadopoulou V, Rozloznik M, Balestra C. Long term effects of recreational SCUBA diving on higher cognitive function. Scandinavian Journal of Medicine \& Science in Sports. 2014; 24: 928-934; DOI: 10.1111/sms.12100

2. Plaza JC, Ruiz EJGF, García JJL, Conde LC. Prediction of human adaptation and performance in underwater environments. Psicothema, 2014; 26: 336-342; DOI: 10.7334/psicothema2014.5

3. Van Wijk, C., \& Waters, A.H. (2001). Personality characteristics of South Afri- can Navy divers. Undersea and Hyperbaric Medicine, 28, 25-30;

4. Van Wijk, C. (2002). Comparing personality traits of Navy divers, Navy non- divers and civilian sport divers. Journal of the South Pacific Underwater Medicine Society, 32, 2-8;

5. Morgan, W.P., Raglin, J.S., \& O'Connor, P.J. (2004). Trait anxiety predicts panic behavior in beginning scuba students. International Journal of Sports Medicine, 25, 314-322. doi:10.1055/s-2004-81582;

6. Slanger, E. \& Rudestam, K.E. (1997). Motivation and disinhibition in high risk sports: Sensation seeking and self-efficacy. Journal of Research in Personality, 31, 355-374;

7. Freixanet, M.G.I. (1999). Personality profiles of subjects engaged in high physical risk sports. Human Performance in Extreme Environments, $4(2), 11-17$

8. McGeoch G, Davis FM. Analysis of a complex recreational scuba diving accident: French Pass, New Zealand, 2000.Diving and Hyperbaric Medicine, 2009; 39: 20-28;

9. Ramírez J, Villaverde C, Oltras C, Ruíz-Villaverde R, Sánchez-Caravaca M. Levels of ACTH and $\beta$-endorphin in the response to stress from open sea scuba diving to $25 \mathrm{~m}$ (3.5 ATA). A field study. International Journal of Sport Psychology. 2004; 35: 1-12;

10. Richter-Levin G. Acute and long-term behavioral correlates of underwater trauma - potential relevance to stress and post-stress syndromes Psychiatry Research. 1998; 79: 73-83;

11. Ladd G. Treatment of psychological injury after a scuba diving fatality. Diving and Hyperbaric Medicine. 2007;37: 36-39;

12. Olszański R, (ed). Selected problems of diving and hyperbaric medicine. Warsaw: Wojskowy Instytut Medyczny, 2017;

13. Olszański R, Radziwon P. The risk of decompression sickness in divers. W: R. Olszański (ed.) Selected problems of diving and hyperbaric medicine. Warsaw : Wojskowy Instytut Medyczny, 2017, s.109-129;

14. Biersner, R.J. (1984). Physical and psychological examination of diver: Psychological standards for diving. In C.W. Shilling, C.B. Carlston, \& R.A Mathias (Eds.), The physician's guide to diving medicine (pp. 520-530). New York, NY: Plenum Press;

15. Biersner, R.J., LaRocco, J.M. (1983). Personality characteristics of US Navy divers. Journal of Occupational Psychology, 56 (4), $329-334$;

16. Biersner, R.J. (1971). Personality factors and risk-taking of professional divers. Medicina dello Sport, 24, 340-345 dostęp z dn 20.02 .2018 http://www.psychomedia.it/pm-cong/2003/diving.htm;

17. Charlston, J.A. (2007). Scuba diving. Berkshire Encyclopedia of Extreme Sports, 267-270

18. Dimmock K, Wilson E. Risking comfort? The impact of in-water constraints on recreational scuba diving. Annals of Leisure Research. 2009; 12 : 173-194;

19. Beneton F, Michoud G, Coulange M, Laine N, Ramdani C, Borgnetta M, Breton P, Guieu R, Rostain J. C, Trousselard M. 19.Recreational Diving Practice for Stress Management: An Exploratory Trial. https://www.ncbi.nlm.nih.gov/pmc/articles/PMC5741699/ dostęp z dnia 20.02.2018;

20. Nevo, B., Breitstein, S., Psychological and Behavioral Aspects of Diving. 1999 ,San Pedro, CA, Best Publishing Company;

21. Bielec G, Błaszkowska J, Waade B., The phenomenon of anxiety in scuba divers. Polish Hyperbaric Medicine and Technology, 2006: 4 (17): 15-20;

22. Steinberg F, Doppelmayr M. A brief note on the relationship between anxiety and performance in scuba diving adolescents: a field study. Perceptual \& Motor Skills: Physical Development \& Measurement, 2015: 120 (3): 960-970; DOI: 10.2466/10.25.PMS.120v16x6

23. Morgan WP. Anxiety and panic in recreational scuba divers. Sports Med. 1995: 20 (6): 398-421;

24. Debski A, Filipek B. Fear in underwater diving accidents. Polish Hyperbaric Research, 2005: 3 (12): 27-29;

25. Yoshihiro Mano. Evaluation of diving stress implication of analysis of work loads https://www.jstage.jst.go.jp/article/joh1959/29/3/29_3_202/_article access on 20.02.2018; Bonnet A, Fernandez L, Piolat
Psychology. 2008; 2: 25-40;

27. Campbell, E Psychological issues in diving. 2016, Retrieved October,16,://www. diversalertnetwork.org/medical/articles/article.asp?articleid=31. dostęp z dnia 19.01.2018;

28. Blumenberg, M., A. Human Factors in Diving. Marine Technology \& Management Group. Berkeley, California: University of California. 27 December 2016

29. Doboszyński T, Łukucijewski B. The effect of hyperbaric oxygen on the human body. Acta Physiol. Pol., 1985; 28 Suppl.: 285-286;

30. Morgan WP, Raglin JS, O'Connor PJ. Trait anxiety predicts panic behavior in beginning scuba students. International Journal of Sports Medicine. 2004; 25: 314-22; DOI: 10.1055/s-2004-815829

31. Raglin JS. Psychobiological antecedents of panic in scuba diving.Performance in Extreme Environments. 1998; 3: 26-29;

32. Anegg U, Dietmaier G, Maier A, Tomaselli F, Gabor S, Kallus KW, Smolle-Jüttner FM. Stress-induced hormonal and mood responses in scuba divers: A field study. Life Sciences, 2002; 70: 2721-2734;

33. Ness GJ, Macaskill N. Preventing PTSD: the value of inner resourcefulness and a sense of personal control of a situation. Is it a matter of problem-solving or anxiety management? Behavioural and Cognitive Psychotherapy. 2003; 31: 463-466;

34. Longo, M. (2003). Psyche and Diving. Psychomedia. Retrieved October 2, 2003, from http://www.psychomedia.it/pm-cong/2003/diving.htm dostęp z dnia 20.01.2018

35. A. Buczyński, J. Buczyński, J. Kocur, J. Roztowski, R. Olszański, The analysis of psychological variables verifying candidates to the profession of a diver. 2002. Polish Hyperbaric Research;

36. Jack, S.J. Ronan, K.R. (1998). Sensation seeking among high- and low-risk sports participants, Personality and Individual Differences, 25, 1063-1083;

37. Behnke A. R. Psychological and psychiatric reactions in diving and submarine warfare. American Journal of Psychiatry. 1945. https://ajp.psychiatryonline.org/doi/abs/10.1176/ajp.101.6.720?code=ajp-site\&journalCode=ajp dostęp z dnia 3.01.2018;

38. Sessa, T., Pallotta, R., \& Fati, S. (1964). Profilo psicologico del subacqueo. Medicina Sportiva, 27, 119-123. http://psychodive.com/psychologyof-diving13/ dostęp $z$ dnia 2.02.2018;

39. Tatarelli, G. (1968). Problemi psicologici della sicurezza subacquea. Medicina Sportiva, 21, 261; http://psychodive.com/psychology-of-diving13/ dostęp z dnia 2.02.2018;

40. Odone, L., Reggiani, E., Oelker, L., Rotunno, R., \& Vassallo, G.M. (1983b). Psychodynamic aspects of sports diving. Minerva Medica, 74(35), 2039-46. http://psychodive.com/psychology-of-diving13/ dostęp z dnia 2.02.2018;

41. Spigolon, L., \& Dell'oro, A (1985). Autogenic training in frogmen. International Journal of Sport Psychology, 16 (4), 312-320. http://psychodive.com/psychology-of-diving13/ access on 2.02.2018;

42. Hunt J. Diving the wreck: risk and injury in sport scuba diving. 1996. http://www.psychomedia.it/pm/grpind/sport/sub2.htm dostęp z dnia 3.02.2018;

43. Knapp, Ronald J., Capel, W C., Youngblood, D. A Stress in the deep: A study of undersea divers in controlled dangerous situations. Journal of Applied Psychology, Vol 61(4), Aug 1976, 507-512.

44. Lewis, V.J., Baddeley, A.D. (1981). Cognitive performance, sleep quality, and mood during deep oxyhelium diving. Ergonomics, 24, 773-793;

45. Anegg U, Dietmaier G, Maier A, Tomaselli F, Gabor S, Kallus KW, Smolle-Jüttner FM. Stress-induced hormonal and mood responses in scuba divers: A field study. Life Sciences, 2002; 70: 2721-2734;

46. Richter-Levin G. Acute and long-term behavioral correlates of underwater trauma - potential relevance to stress and post-stress syndromes Psychiatry Research. 1998; 79: 73-83. 
47. Griffiths TJ, Steel DH, Vaccaro P. Relationship between anxiety and performance in scuba diving Perceptual and Motor Skills. 1979; 48: 10091010;

48. Griffith, T.J., Steel, D.H. and Vaccaro, P., Karpman, M.B. (1981). The effects of Relaxation Techniques on Anxiety and Underwater performance. International Journal of Sport Psychology, 12: 176-182;

49. Bachrach, A.J., \& Egstrom, G.H (1987). Stress and performance in diving. San Pedro (CA): Best Publishing Co:

50. Colodro J, Garcés de los Fayos E, Velandrino A. Personality differences in the psychological fitness for military diving. Anales de Psicología 28, 434-443. http://www.tandfonline.com/doi/ref/10.1037/mil0000073?scroll=top dostęp z dnia 2.02.2018;

51. Coetzee N .Personality profiles of recreational scuba divers. African Journal for Physical Activity and Health Sciences https://www.ajol.info/index.php/ajpherd/article/view/63416 dostęp z dnia 14.02.2018;

52. Morgan WP. Anxiety and panic in recreational scuba divers. Human Performance in Extreme Environments. 1996; 1: 20-35;

53. Karasek, R. A. , Theorell, T. Healthy Work: Stress, Productivity and the Reconstruction of Working Life, 1990. New York: Basic Books.

54. Lazarus, R.S. \& Folkman S. Stress, appraisal and coping.1984. New York: Springer Publishing Company.

55. MacLachlan M. (red). Maritime Psychology.Research in Organizational \& Health Behavior at Sea. 2017. New York: Springer Publishing Company.

dr Dorota Niewiedział

Zakład Psychologii Rozwoju Człowieka

Uniwersytet Zielonogórsk

Al. Wojska Polskiego 69

65-762 Zielona Góra

d.niewiedzial@wpps.uz.zgora.pl 